\title{
Role of Youths in Agricultural Development in Makurdi Local Government Area of Benue State
}

Daudu, S; Okwoche, V. A. and Adegboye, O. G

Department of Agricultural Extension

University of Agriculture, Makurdi

\begin{abstract}
The study investigated the role of youths in agricultural development in Makurdi Local Government area (LGA) of Benue State. Interview schedules were used to collect data from 120 youths selected through random sampling procedure from Makurdi LGA. Descriptive and inferential statistics namely, mean and factor analysis respectively were used to analyze the data. The result shows that youths play important roles in the supply of labour, donation of materials, initiating of projects, attend meetings punctually and use initiatives to gain outside help. Also, participation of youths in community based non-formal rural youth agricultural programmes is mainly in youth organizations which includes, age grades, local social clubs and young farmers organization. The major problems that inhibit youth participation in agricultural activities were lack of commitment, lack of logistic support and lack of land ownership. It was recommended that a robust relationship between agencies interested in encouraging youth involvement in agriculture should be evolved through legislation and implementation of policies to guarantee training programmes, credit facilities and land accessibility to youths at the identified rural youth organizations. This will enhance youth involvement and catalyze agricultural development.
\end{abstract}

Key words: Youths, agricultural development, roles, problems.

\section{INTRODUCTION}

The poor state of youth participation in agricultural activities in Nigeria has been a matter of great concern among agriculturists, agricultural researchers as well as administrators. This is because the present poor state of decline in agricultural production has dimmed the hope of raising the level of agricultural production to ensure sustainable food security for the ever increasing population of Nigeria.

One of the major setbacks of agricultural development programmes is attributed to the inability of the federal government to integrate youths into the mainstream of the numerous agricultural development programmes implemented over the years (ljere, 1992). For a country to attain economic stability the agricultural sector must be vibrant and the youths encouraged to imbibe farming as a noble profession (Ojediran, 1997).

Youths have the potential to overcome some of the major constraints to expanding animal production in developing countries such as pest control, feeding, genetic improvement and protection against predators because they are often more open to new ideas and practices 
Journal of Agricultural Extension

Vol. 13 (2) December 2009

than adult farmers. They play an important role in awareness raising on different subjects (ljere, 1992).

Mobilizing the youths for national development is a common phenomenon amongst the western and developing countries. In such countries as Great Britain, Netherlands, Denmark, Germany, the United States of America and Tanzania, the involvement of youths in agricultural production through youth programmes had contributed significantly to agricultural development and empowering the citizenry and youths to always meet the full needs and deep seated aspiration to be self sufficient in food production (FAO, 1990). Indeed, since the youths are the future of any country, it is useful to develop them into patriotic citizens, future progressive farmers and better citizens. The youth clubs are the nurseries for them (Ajayi, 2006).

The poor state of agricultural productivity and low esteem of agriculture as manifested in rural-urban migration, youths' low interest in farming, lack of industrial firms to process agricultural products and skilled labour among others has led to worsening Nigerian food deficit (NDE, 2006). The realization of this situation led the federal government to embark on ways to revitalize the poor food situation by constructively involving youth in agriculture at secondary school level. This was through the national policy on education which made practical agriculture a core subject at the junior and secondary school level and agricultural science as a vocational subject (FMAWD, 1989).

In order to involve youth in agriculture to reap the benefit of the constructive engagement of youth in agriculture, the question relates to the following questions: What is the role of youths in agricultural development in the study area? In which community based non-formal youth agricultural educational programmes do youths participate? Which problems inhibit youth participation in agricultural activities?

The purpose of the study was to determine the role of youths in agricultural development in Makurdi LGA of Benue State. The specific objectives of the study were to determine: the nature and extent of youth involvement in agricultural development; their participation in community based non-formal youth agricultural education programes and the problems that inhibit youth involvement in agricultural activities.

\section{METHODOLOGY}

The study area is Makurdi Local Government Area (LGA), Benue State. Makurdi is the headquarters of Benue State, is located on the banks of River Benue. It is inhabited by the Tiv ethnic group with Idoma, Jukun and Hausa also residing in the area. Its people are primarily of agrarian rural economy.

The population of the study consisted of youths in Makurdi LGA.Twenty youths were selected from each of ten council wards in Makurdi LGA. A total of 120 respondents were selected through random sampling technique covering the LGA. Questionnaires were used to collect the data.

In order to determine the nature of youth role in agricultural activities, a three point Likert-type scale with responses ranging from not at all, moderate and high and scaled $1-3$ respectively were utilize to rate statements on nature of role in agricultural activities obtained from relevant literature. Similarly, in order to determine the level of youth participation in community based non-formal youth agricultural education, a three point Likert type scale with response options; Not at all, moderate and high and scaled $1-3$ respectively were utilized. In both cases, the mean responses greater or equal to 2 were regarded as important while mean responses lower than 2 were regarded as not important. Also, in order to determine the 
problems inhibiting youth participation in agricultural activities, a list of possible problems that inhibit youth's participation from literature were presented to respondents. This was measured on a 3- point Likert type scale with: not at all, moderate and high and with scores of 1,2,3 respectively. This was analyzed by use of factor analysis technique Kaisser criterion of using factor loadings of 0.30 and above were used in naming the major problems.

\section{RESULTS AND DISCUSSIONS}

\section{Youth involvement in agricultural activities}

Result of analysis in Table 1 indicate that the use of initiative to gain outside help $(\bar{x}=$ 2.89), supply of labour $(\bar{x}=2.68)$, being punctual at meetings $(\bar{x}=2.65)$, initiating agricultural projects $(\bar{x}=2.43)$ and donation of materials $(\bar{x}=2.28)$ were important ways youths are involved in agricultural activities. This implies that most of the youths were involved in these aforementioned ways in promoting involvement in agricultural development. According to Lloyd (1965) youths get involved in agricultural activities by cooperation with extension service through attending meetings, conducting of agricultural demonstration and assisting at local agricultural farms.

TABLE 1: Youth involvement in agricultural activities

\begin{tabular}{lcc}
\hline \multicolumn{1}{c}{ Nature and extent of involvement } & Mean score & Remark \\
& $(\mathrm{x})$ & $*$ \\
Supply of labour & 2.28 \\
Donation of materials & 2.43 \\
Initiating agricultural projects & 1.52 \\
Giving financial support & 2.65 \\
Being punctual at meetings & 2.89 \\
Use of initiative to gain outside help & $*$ \\
* Important & \\
Source: Field survey, 2007 & \\
& \\
Participation of youths in community based non-formal rural youth agricultural education \\
programmes \\
$\quad$ Result of analysis in Table 2 shows that most of the respondents regarded the following \\
rural institutions as important means of youth participation in community based non-formal rural \\
youth agricultural education programmes, namely, young farmers organization (x = 2.68), age \\
grade (x = 2.58), and local social clubs (x = 2.48) in descending order. This implies that avenues \\
open for youth participation in community based non-formal rural youth agricultural education \\
programmes were young farmers organization, age grades and local social clubs. This is \\
probably because youth often congregate in organizations where they can interact with their \\
kinds on all issues affecting youth welfare. Agricultural education programmes offer a chance for \\
youth welfare and play an important role in diffusing information related to new strategies of \\
agricultural production (Ajayi, 2006).
\end{tabular}


Journal of Agricultural Extension

Vol. 13 (2) December 2009

TABLE 2: Participation of youths in community based non-formal rural youth agricultural education programmes

\begin{tabular}{lcc}
\hline $\begin{array}{l}\text { Community based non-formal rural youth } \\
\text { agricultural education programmes }\end{array}$ & $\begin{array}{c}\text { Mean score } \\
(\overline{\mathrm{x}})\end{array}$ & Remark \\
\hline & & $*$ \\
Local social clubs & 2.48 & \\
Age-grades & 2.58 & \\
Religious groups & 1.65 & $*$ \\
Community cooperatives & 1.99 & \\
Young farmers organizations & 2.68 & \\
\hline
\end{tabular}

* Important

Source: Field survey, 2007

\section{Problems that inhibit youth participation in agricultural activities}

Table 3 shows that the major factor that inhibit youth participation in agricultural activities as perceived by respondents. Based on the item loadings, factors 1, 2 and 3 were named lack of commitment, lack of logistic support and land insecurity respectively.

The specific issues that define lack of commitment (factor 1) include poor organization (0.358), unavailability of labour (0.690), many commitments (0.710) and lack of cooperation (0.810).

On the other hand, lack of logistics was dominated by inadequate publicity $(0.318)$, inadequate finance $(0.744)$, poor government commitment $(0.475)$, and lack of technical skills (0.626) while lack of land ownership was defined by lack of land ownership (0.859).

A further consideration of the major problems enables us to appreciate the synergy of the items resulting in the naming of the major problem. Lack of commitment defined as organizational or individual lapses. Under this major problem, poor organization, unavailability of labour, many commitments and lack of cooperation are inherently built in the organization or individual and could be ameliorated through training of management or individuals. Lack of commitment is an endemic issue in management of project/programmes. According to Ayoola (2001), one of the problems of agricultural development projects is lack of sustained commitment by stakeholders in term of funding, support and supervision which may result into the project not been fiscally empowered, resulting in project failure.

On the other hand, lack of logistic support is closely linked to lack of commitment, lack of logistic support is defined as inability of the stakeholder to avail the project of the necessary resources to accomplish the project. Under this major problem, inadequate publicity, inadequate finance, poor government and lack of technical skills are issues that could hinder youth participation in agricultural activities.

Lack of land ownership (factor 3 ) was amplified by lack of land ownership (0.859).Lack of land ownership refers to lack of land to be used on a sustainable level owing to lack of ability to own it on a permanent basis. Land ownership is a deleterious problem in agricultural 
production and is not limited to age or gender. According to Onucheyo (1998) in order to drastically improve food production, we need to put some policies in place immediately to among others facilitate or liberalize land ownership by those interested in agricultural production.

TABLE 3: Rotated component matrix of problems inhibiting youth participation in agricultural activities

\begin{tabular}{lccc}
\hline Problem & \multicolumn{3}{c}{ Major Problem } \\
\cline { 2 - 4 } & $\mathbf{1}$ & $\mathbf{2}$ & $\mathbf{3}$ \\
\hline Inadequate publicity & 0.171 & 0.318 & 0.658 \\
Poor organization & 0.358 & 0.562 & 0.339 \\
Inadequate finance & $-3.024 \mathrm{E}-02$ & 0.744 & $4.049 \mathrm{E}-02$ \\
Unavailability of labour & 0.690 & -0.212 & 0.159 \\
Many commitment & 0.710 & $3.727 \mathrm{E}-02$ & $-2.264 \mathrm{E}-02$ \\
Lack of cooperation & 0.810 & $6.567 \mathrm{E}-02$ & $-7.601 \mathrm{E}-02$ \\
Poor government commitment & -0.139 & 0.495 & $-4.361 \mathrm{E}-02$ \\
Lack of land ownership & $-7.788 \mathrm{E}-02$ & -0.475 & 0.859 \\
Lack of technical skills & $3.575 \mathrm{E}-02$ & 0.626 & $2.965 \mathrm{E}-02$ \\
\hline
\end{tabular}

$\begin{array}{rlll}\text { Key: Problem 1 } & = & \text { Lack of commitment } \\ 2 & = & \text { Lack of logistic support } \\ 3 & = & \text { Lack of Land ownership }\end{array}$

\section{CONCLUSION}

The ways of youths involvement in agricultural activities were: use of initiative to gain outside help, supply of labour, attending meetings punctually, initiating projects and donating of materials. Also, the important community based non-formal rural youth agricultural education programme were young farmers organization, age grade and local social clubs, while major problems inhibiting youth participation in agricultural activities were lack of commitment, lack of logistic and land insecurity.

\section{RECOMMENDATION}

It was recommended that agencies interested in involving youths in agricultural development should put policies in place using the identified nature of youth involvement in agriculture determined by the study to ensure youth involvement in agricultural development. 
Journal of Agricultural Extension

Vol. 13 (2) December 2009

Secondly, the important community based non-formal rural youth agricultural education programmes identified could serve as veritable foci for successful agricultural education to empower youth to take their rightful place in agricultural development. While the major problems inhibiting youth participation in agricultural activities identified in the study should be ameliorated using appropriate policy options, for instance engendering commitment by government through appropriate legislative appropriation and budgetary commitment, ensures that appropriate logistic in form of credit is provided and ensuring that land is made available to youth agricultural activities through relevant legislation and policy implementation.

\section{REFERENCES}

Ajayi, A. R. (2006). A guide for young farmers clubs programme. Akure. SAC Impressions.

Ayoola, G. B. (2001). Essays on the Agricultural Economy, a Book of Readings on Agricultural Policy and Administration in Nigeria Vol. 1 Ibadan, Nigeria. TMA Publishes.

Federal Ministry of Agriculture and Water Development (FMAWD) (1989). A Perspective Plan for Agricultural Development in Nigeria (1990 - 2005) FMAWRRD.

Food and Agriculture Organization (1999). Report of an Expert Consultation on Rural Youth by Young Farmers in Developing Countries, Rome FAO.

Ijere, M. O. (1992). Leading Issues in Rural Development. Enugu. ACENA Publisher Ltd.

Lloyd, J.P(1965). Hand book on Agricultural Education in Public Schools. Interstate printers and publishers, Inc, Danville, Illinois.

National Directorate of Employment (NDE). Agricultural Programme (2006). Guidelines on Graduate Agricultural Employment Scheme. The Job Creator Feb. Vol. 7 No. 3 pp.3- 6.

Ojediran, B. (1997). Battling the Risk of Managing Agriculture, Lagos: The

Guardian Daily Newspaper, April, $10^{\text {th }}$.

Onucheyo, E. (1989). Political Decision in the Nigerian Agricultural Industry, Kongo-Zaria. Tamaza Publishing Co. Ltd. 